\title{
Exaggerated Mini Puberty during Early Infancy of a Preterm Girl: A Case Report and Review of Literature
}

\author{
Mohamad Ahangar Davoodi, MD ${ }^{1 *}$; Fatemeh Ghobadi, MD²; Golsa Mahmoudi ${ }^{3}$; Amir Almasi-Hashiani, PhD \\ ${ }^{1}$ Department of Pediatric Endocrinology, Arak University of Medical Sciences, Arak, Iran \\ ${ }^{2}$ Department of Radiology, Qods Hospital, Arak, Iran \\ ${ }^{3}$ Department of Nursing, Amir Kabir Hospital, Arak University of Medical Sciences, Arak, Iran \\ ${ }^{4}$ Department of Epidemiology, School of Health, Arak University of Medical Sciences, Arak, Iran
}

\begin{abstract}
Mini puberty is the important period of infancy life that can have a serious impact on sexual development in both sexes. In the infants born very preterm and with extremely low birth weight, mini puberty changes including changes in clinical, hormonal, and imaging data are severe and long lasting, especially in girls. It can be called "exaggerated mini puberty". In this study, a 6-month preterm infant with bronchopulmonary dysplasia presented with periodic vaginal bleeding, Tanner stage 3 breast development, and Tanner stage 2 pubic hair. We did follow up clinical and para-clinical evaluations for the infant during one year and compared the obtained data with those of similar published articles. During one year of monitoring, the case gradually grew to the normal pre-pubertal state, without any hormonal suppressive treatment. Exaggerated mini puberty is a temporary physiologic state in very low birth weight (VLBW) preterm infants that does not require any extra hormonal and surgical interventions.

Keywords: Estradiol, Gonadotropin, Hypothalamic-pituitary-gonadal, Mini puberty, Preterm

Cite this article as: Ahangar Davoodi M, Ghobadi F, Mahmoudi G, Almasi-Hashiani A. Exaggerated mini puberty during early infancy in preterm girls: a case report and review of literature. Arch Iran Med. 2022;25(1):64-70. doi: 10.34172/aim.2022.09
\end{abstract}

Received: March 10, 2021, Accepted: May 11, 2021, ePublished: January 1, 2022

\section{Introduction}

Gonadotropin-releasing hormone secretion from 1718 weeks of fetal life causes an increase in luteinizing hormone $(\mathrm{LH})$ and follicle-stimulating hormone (FSH), followed by a decrease in gonadotropins during the last months of embryonic stage. Reducing trends of sexual hormones are observed due to the fetal placental estrogen negative feedback. ${ }^{1}$ Temporary activation of the HPG axis (hypothalamus-pituitary gonad) during the first months of life is called "mini puberty" which was first described in $1970 .^{2,3}$

In male infants with mini puberty, LH serum level is dominant while in female infants, FSH serum level is dominant. ${ }^{4}$ In both sexes, LH levels ordinarily decrease by 6-9 months of age, but in females, FSH levels might stay high, up to the age of 3-4 years. ${ }^{4,5}$ Testosterone levels in boys start to increase after 1 week of age, peak at pubertal levels in 1-3 months, then decline to low pre-pubertal levels by approximately 6 months of age. ${ }^{4}$ Estradiol level is high at delivery for girls and decreases within the first week of life. It increases to $5-50 \mathrm{pg} / \mathrm{mL}$ between the days 30 to 60 and then falls to about $15 \mathrm{pg} / \mathrm{mL}$. ${ }^{6}$ The estradiol fluctuation in girls is probably due to the growth and atrophy of the follicles and reaches the pre-puberty level by the age of 2 years but it peaks at the age of 6 months. ${ }^{6}$

In male infants, androgen exposure of mini-puberty also predicts later sex-typed trait (brain masculinization) and longitudinal good testicular functions such as spermatogenesis, penile and testicular size, and prostate growth. ${ }^{4,5}$ In girls, the uterus and breasts enlarge, but sebaceous gland, acne development, and transient pubic hair are seen in both sexes. ${ }^{4,6}$ In contrast to males, the imprint of mini puberty in future development of women's sexual limbs, trait, and reproductive systems is not known. ${ }^{6}$

Levels of gonadotropins, especially FSH, are higher in preterm infants compared to term newborns and stay high for a longer period of time, particularly in girls. In $38 \%$ of the studied preterm girls, FSH was higher than 4.5 IU/L. In addition, higher levels of testosterone and faster growth of the testicles and penis are observed among the premature boys compared to term infants. Also, FSH levels are higher in small for gestational age (SGA) infants compared to appropriate for gestational age (AGA) ones. ${ }^{6}$

In congenital hypogonadotropic hypogonadism, both fetal and postnatal pituitary gonadotropin secretions are low, presenting with micro phallus, undescended testis (cryptorchidism), and absence of mini puberty changes in infancy., ${ }^{4,8}$ The infant with $45, \mathrm{X}$ (pure turner not another mosaicism) shows higher FSH levels than normal and the levels may remain elevated up to 6 years of age. ${ }^{9}$ Absence of mini puberty presentations in the infancy is helpful for diagnosing some disorders such as Turner's syndrome and congenital hypogonadotropic hypogonadism. ${ }^{6}$ Therefore, mini puberty is a golden time window to diagnose and treat congenital hypogonadotropic hypogonadism boys in infancy. ${ }^{1,5,10,11}$ 
In infants with difference in sex development at the mini-puberty phase, the LH/FSH ratio of 0.32 is helpful to distinguish the infant boys from girls., ${ }^{5,12}$ In the minipuberty ultrasonography data, the height of the uterus is $35 \mathrm{~mm}$ and the highest width is around $14 \mathrm{~mm}$. About $25 \%$ of the infants have a little fluid in the endometrial space. In $84 \%$ of the infants, follicles with diameters under $1 \mathrm{~cm}$ are observed. ${ }^{6}$ In this study, we aimed at reporting a mini puberty case and presenting a systematic review on published mini puberty cases.

\section{Case Report}

We studied a 6-month preterm infant with periodic vaginal bleeding, Tanner stage 3 breast development and Tanner stage 2 pubic hair. She did not have breasts at birth. Serum estradiol, LH, and FSH levels were measured using chemiluminescence assay (Siemens instruments model Immulite XP2000, USA). All ultrasonography examinations were performed and reported by an expert sonologist. The patient was followed up by a pediatric endocrinologist for one year. Ensuring confidentiality, the parents agreed to participate through a written informed consent.

We systematically searched the three main international databases to find the related published papers including PubMed/Medline, Scopus, and ISI/Clarivate Analytics. Searches were done from the start (1985) to April 2020 and all English full-text papers were included in this study.

The research strategy used a combination of some related keywords including, exaggerated mini puberty, mini puberty, very low birth weight (VLBW), infancy, preterm and premature, hypothalamus-pituitary-gonadal axis, excessive ovarian stimulation syndrome, and $\mathrm{GnRH}$ agonist agents and case reports. Among retrieved records,
14 cases from 8 studies were included in this systematic review. Analyses were done using Stata software version 13.

A six-month-old infant with a weight of $4100 \mathrm{~g}$, height of 55-centimeter, and head circumference of $37.5 \mathrm{~cm}$ was brought to the clinic due to symptoms of sexual prematurity including periodic vaginal bleeding ( 2 times), Tanner stage 3 breast development, and Tanner stage 2 pubic hair.

The infant was born after a preterm labor of 25 weeks of gestation, with a birth weight of $800 \mathrm{~g}$, and a history of 50-day NICU hospitalization. Due to bronchopulmonary dysplasia and congenital hypothyroidism, she was taking levothyroxine $25 \mathrm{mcg}$ daily, hydrochlorothiazide, furosemide, Atrovent, and Flixotide oral inhalers, and she was oxygen-dependent.

Central precocious puberty (CPP) was obvious in laboratory evaluations including estradiol $54.9 \mathrm{pg} / \mathrm{mL}, \mathrm{FSH}$ $4.1 \mathrm{mUI} / \mathrm{mL}$, and LH $5.3 \mathrm{mUI} / \mathrm{mL}$. Other lab results were normal except ferritin, which is reasonable considering the inflammatory process of the patient's " bronchopulmonary dysplasia (BPD)" and became normal within eight months of monitoring. Furthermore, sonography examinations revealed a uterine size of $1.4 \times 21 \times 17 \mathrm{~mm}$ and volume of 2.1 milliliter (cc), endometrial thickness of $4.4 \mathrm{~mm}$, cervical length of $18 \mathrm{~mm}$, and ovarian diameters of 1.3 and $3.5 \mathrm{~mm}$ with $6.6 \mathrm{~mm}, 8.8 \mathrm{~mm}$ and $10.5 \mathrm{~mm}$ follicles. Laboratory evaluations were consistent with CPP.

Hypothalamus-pituitary axis and its MRI with and without contrast were normal. On monthly assessments, after two months the infant breast size became slightly smaller but it was still at stage-3, pubic hair disappeared but menarche was continued and a decrease in gonadotropins and estradiol levels was observed in the test results (Table 1).

Due to the regression of clinical presentation and

Table 1. The Infant Puberty Presentations; Clinical, Laboratory and Radiology Changes During the Monitoring

\begin{tabular}{|c|c|c|c|c|c|c|}
\hline Age & Presentation & $\begin{array}{c}\text { LH } \\
(\mathrm{mlU} / \mathrm{mL})\end{array}$ & $\begin{array}{c}\text { FSH } \\
(\mathrm{mIU} / \mathrm{mL})\end{array}$ & $\begin{array}{c}\text { Estradiol } \\
(\mathrm{pg} / \mathrm{mL})\end{array}$ & $\begin{array}{l}\text { Ferritin } \\
(\mathrm{ng} / \mathrm{mL})\end{array}$ & Sonography \\
\hline 6 months & $\begin{array}{l}\mathrm{VB}+ \\
\mathrm{B} 3 \\
\mathrm{PH}: 2\end{array}$ & 5.3 & 4.1 & 54.9 & 1118 & $\begin{array}{c}\text { Utreus: } 21 \times 11.4 \times 17 \mathrm{~mm}=2.1 \mathrm{cc} \\
\text { Endometrium: } 4.4 \mathrm{~mm} \\
\text { Ovaries }\left\{\begin{array}{l}L: 17 \times 10.5 \times 14 \mathrm{~mm}=1.35 \mathrm{cc} \\
R: 24 \times 18 \times 14.5 \mathrm{~mm}=3.5 \mathrm{cc}\end{array}\right. \\
\text { Follicles: } 10.5,8.8,3.5 \mathrm{~mm}\end{array}$ \\
\hline 7 months & $\begin{array}{l}\mathrm{VB}+ \\
\mathrm{B}: 3 \\
\mathrm{PH}: 2\end{array}$ & 5.01 & 4.4 & 29.3 & 568 & - \\
\hline 8 months & $\begin{array}{l}\mathrm{VB}+ \\
\mathrm{B}: 3 \\
\mathrm{PH}: 1\end{array}$ & 1.21 & 2.79 & 20.28 & & - \\
\hline 9 months & $\begin{array}{c}\text { VB }+(\text { spotting }) \\
B: 2\end{array}$ & 0.79 & 2.11 & 14.23 & 187.7 & $\begin{array}{c}\text { Uterus: } 23 \times 11 \times 11.5 \mathrm{~mm}=2 \mathrm{cc} \\
\text { Ovaries }\left\{\begin{array}{l}L: 15 \times 6.5 \times 13 \mathrm{~mm}=0.7 \mathrm{cc} \\
R: 18 \times 10 \times 18 \mathrm{~mm}=1.7 \mathrm{cc}\end{array}\right. \\
\text { Follicles: } 6.5,6,5.5 \mathrm{~mm}\end{array}$ \\
\hline 13 months & B:bud & 0.65 & 2.9 & 30.68 & 51.68 & $\begin{array}{c}\text { Uterus: } 29 \times 15 \times 7 \mathrm{~mm}=1.8 \mathrm{cc} \\
\text { Ovaries }\left\{\begin{array}{c}L: 17 \times 13.5 \times 7.5 \mathrm{~mm}=0.9 \mathrm{cc} \\
R: 18 \times 12 \times 8 \mathrm{~mm}=0.9 \mathrm{cc}\end{array}\right. \\
\text { Follicles: } 8.5,9 \mathrm{~mm}\end{array}$ \\
\hline 18 months & Pre pubertal & 0.08 & 1.63 & 8.31 & 50.16 & - \\
\hline
\end{tabular}


para clinical data, patient puberty continued to be monitored without treatment. After 4 months, breast size decreased to Tanner stage 2 and vaginal bleeding stopped (Figure 1). Reduction of puberty symptoms, laboratory improvements, and sonography during one year continued until clinical symptoms returned to prepuberty stage. The tests showed an LH level of 0.08, FSH level of 1.63 , and estradiol level of 8.3. Also, sonography examinations reported a uterine size of $1.8 \mathrm{cc}$ and ovarian volume of $0.9 \mathrm{cc}$ (Table 1 ).

Fortunately, she could stand and walk with help. The oxygen demand decreased to bedtime at the age of 16 months, and 2 months later (at the age of 18 months) she could stand without oxygen therapy. The patient's weight reached $8600 \mathrm{~g}$ (10th percentile), her height reached 78 $\mathrm{cm}$ (25th percentile), and her head circumference reached $43.5 \mathrm{~cm}$. Thyroid function tests were under control with levothyroxine $25 \mathrm{mg}$ /daily during one year. All the abovementioned symptoms could be explained by exaggerated mini puberty during infancy due to prematurity that showed improvement in severe puberty symptoms without any extra treatment.

\section{Discussion}

Fourteen mini puberty cases from eight studies were included in this systematic review. The mean preterm birth GA of infants with exaggerated mini puberty symptoms was 26.3 weeks, (SD: 2.6, range: 24-33 weeks) and the mean birth weight was $963 \mathrm{~g}$ (SD: 345, range: 625-1590). Almost all of them had a history of long-term hospitalization for prematurity problems, especially BPD, and required long-term oxygen therapy. They also had retinopathy of prematurity (ROP), apnea of prematurity, patent ductus arteriosus (PDA), and intracranial hemorrhage (ICH) (Table 2). There was no case of persistent precocious puberty in the search.

The mean onset of obvious signs of puberty in these infants was 39.28 weeks, (SD: 4.5 , range: 30-48 weeks) and on the average, it was 3.5 months after birth (SD: 1.4, range: 3 weeks to 6 months). A wide variety of sex maturity presentations were reported including swelling labia major, thelarche, periodic vaginal bleeding, and sometimes pubarche.

The age of termination of puberty symptoms was very diverse from about 2 weeks to 13 months, which can be related to the severity of puberty, medical interventions, or monitoring techniques (Table 2).

In these studies, the wide variety of hormonal levels due to the severity of gonadotropin secretion, the subsequent stimulation of the ovaries, and the enlargement of follicles secreting estradiol in the puberty level, can reflect the immaturity of the negative feedback mechanism in HPG axis in the premature infants. ${ }^{7,13}$ There was no significant correlation between hormone levels (i.e., levels of LH, FSH, and estradiol) and GA, weight at birth, age at onset of puberty changes, and age at complete regression.

It is very important to note that in all the articles, the gradual decline of these hormonal changes strongly confirms that this pattern is a transient state. Interestingly, in patients who had undergone therapeutic interventions, such as oophorectomy, GnRH agonist therapy, and medroxyprogesterone acetate (MPA), no signs of puberty were observed, even after discontinuation of treatment, which also confirms the temporary state of the hormonal changes. ${ }^{13-15}$

Note that all symptoms have been considered and recorded according to the referrals of these patients, and they all might not have always been reported due to the variety and lower severity of some of the symptoms, lack of attention and knowledge of the parents, or the routine examinations of infants by the doctors. Therefore, these clinical and paraclinical (according to lab data and ultrasound findings) changes do not cover unusual or less common symptoms in VLBW preterm infants which are usually neglected. ${ }^{13}$

During the first two years of life, high levels of gonadotropins have several roles in sexual development such as brain masculinization, longitudinal good testicular function (spermatogenesis), penile and testicular size, prostate growth in men and uterine and breast enlargement in girls, and the development of sebaceous gland, acne, and transient pubic hair in both sexes. ${ }^{5,16,17}$ In premature infants, the exaggerated mini puberty state is observed with severe puberty exchange in clinical, laboratory, and ultrasonography data.

Serum levels of gonadotropins, especially $\mathrm{FSH}$, are higher and more extended in preterm infants than in term newborns, particularly in girls. In both sexes, the LH level ordinarily decreases by 6-9 months of age, but in premature infants, it takes longer than one year. ${ }^{6,8}$

In the case of this study, periodic vaginal bleeding was seen similar to three studies. ${ }^{6,15,18}$ However, that is not a usual event in mini puberty state in term infants. It is not necessary to use GnRH agonist in this undesirable state in the premature infants. However, Perez-Milicua et $\mathrm{al}^{15}$ started leuprolide injection every 28 days and discontinued it at the age of two, similar to the study by de Lange et al After stopping hormonal therapy, signs of puberty did not develop and the initial diagnosis of CPP was incorrect. ${ }^{14}$

Like Kurtoğlu and Baştuğ's study, ${ }^{6}$ but unlike the studies conducted by Perez-Milicua et $\mathrm{a}^{15}$ and Vogiatzi et al, ${ }^{18}$ our case had pubic hair. This symptom is the consequence of gonadal and adrenal androgen secretions concomitant with the LH changes in the mini-puberty. ${ }^{6}$

By regression of puberty symptoms in the patient of this study during 12 months of monitoring, we observed disappearance of pubarche hair, discontinuation of vaginal bleeding after 4 months, and complete evanescence of breast bud at the 8th month of follow up (Figure 1).

The complete regression of puberty symptoms in our patient continued about 1 year due to severity of the primary presentation, although in other studies, it lasted from 2 weeks to 10 months due to lower severity of symptoms such as edema of the labia majora. ${ }^{13,18-20}$ 
Altogether, the severity of prematurity is not necessarily associated with the severity and variety of puberty presentation and the duration of symptoms.

Most of the patients in similar articles also had longterm hospitalization due to bronchopulmonary dysplasia, recurrent prematurity apnea, primary pulmonary hypertension, PDA, ROP, and even $\mathrm{ICH}$, all of which are the causes of inflammatory mechanisms in the body. ${ }^{13,15,18,20}$ Synchronization of reduction in sex hormones and inflammatory markers (ferritin) may indicate that the inflammatory process is an irritant marker for exaggerated puberty during the infancy period (Table 1). Likewise, in the current case study, gradual regression of puberty symptoms was concomitant with the recovery of BPD

Table 2. The Review of all Reported Cases of Mini Puberty of Early Infancy in the Preterm Girls Including Clinical, Laboratory and Radiology Changes During the Monitoring

\begin{tabular}{|c|c|c|c|c|c|c|c|c|c|}
\hline Studies & $\begin{array}{l}\text { Birth } \\
\text { GA }\end{array}$ & Weight & $\begin{array}{c}\text { Background } \\
\text { Disease }\end{array}$ & $\begin{array}{l}\text { Drugs and } \\
\text { Interventions }\end{array}$ & $\begin{array}{l}\text { Age at } \\
\text { Onset of } \\
\text { Puberty } \\
\text { Changes }\end{array}$ & $\begin{array}{l}\text { Clinical } \\
\text { features }\end{array}$ & $\begin{array}{l}\text { Prime Levels of } \\
\text { Hormones }\end{array}$ & $\begin{array}{c}\text { Sonography } \\
\text { Findings }\end{array}$ & $\begin{array}{c}\text { Age at } \\
\text { Complete } \\
\text { Regression }\end{array}$ \\
\hline $\begin{array}{l}\text { Ahangar Davoodi } \\
\text { (index patient) } \\
2020\end{array}$ & $25 w k$ & $800 \mathrm{~g}$ & $\begin{array}{c}\text { BPD } \\
50 \text { days } \\
\text { hospitalization } \\
\mathrm{CH}\end{array}$ & $\begin{array}{c}\text { Oxygen } \\
\text { dependent } \\
\text { Levothyroxine } \\
\text { Atrovent } \\
\text { Flixotide } \\
\text { Furosemide }\end{array}$ & $\begin{array}{l}39 \text { weeks } \\
\text { from GA } \\
\text { (4 months) }\end{array}$ & $\begin{array}{c}\text { VB } \\
\mathrm{B}: 3 \\
\mathrm{PH}: 2\end{array}$ & $\begin{array}{c}\mathrm{LH}: 5.3 \mathrm{mUI} / \mathrm{mL} \\
\text { FSH: } 4.1 \mathrm{mUl} / \mathrm{mL} \\
\text { Est: } 54.9 \mathrm{pg} / \mathrm{mL}\end{array}$ & $\begin{array}{c}\text { Uterus: } 21 \\
\text { mm } \\
=2.1 \mathrm{cc} \\
\text { Ovaries: } \\
1.35 \mathrm{cc}, 3.5 \\
\text { cc } \\
\text { Follicles: } \\
10.5 \mathrm{~mm} \\
\text { (Right ovary) } \\
8.8 \mathrm{~mm}\end{array}$ & 18 months \\
\hline \multirow{3}{*}{ Vorgucin 2018} & $25 w k$ & $740 \mathrm{~g}$ & $\begin{array}{l}\text { PPD, PDA, } \\
\text { GERD, } 3 \text { month } \\
\text { Hospitalization }\end{array}$ & - & $\begin{array}{l}39 \text { weeks } \\
\text { from GA } \\
\text { (4 months) }\end{array}$ & $\begin{array}{c}\text { VB: } \\
\text { Once more } \\
\text { B:2 } \\
\text { Vulvar, } \\
\text { clitoris } \\
\text { Pubic } \\
\text { swelling }\end{array}$ & $\begin{array}{c}\mathrm{LH}: 18 \mathrm{mUI} / \mathrm{mL} \\
\text { FSH:6.6 mUl/mL } \\
\text { Est: } 246 \mathrm{pg} / \mathrm{mL}\end{array}$ & $\begin{array}{l}\text { Multiseptated } \\
\text { cyst } \\
\text { Right ovary } \\
16 \mathrm{~mm}\end{array}$ & 11 months \\
\hline & 25 wk & $1000 \mathrm{~g}$ & BPD, ROP, ICH & - & $\begin{array}{l}39 \text { weeks } \\
\text { from GA } \\
\text { (4 months) }\end{array}$ & $\begin{array}{l}\text { Genital, } \\
\text { pubic } \\
\text { swelling }\end{array}$ & $\begin{array}{c}\mathrm{LH}: 21.3 \mathrm{mUl} / \mathrm{mL} \\
\text { FSH:7.2 mUl/mL } \\
\text { Est:276 pg/mL } \\
\text { 17ohp:7.3 ng/mL }\end{array}$ & $\begin{array}{c}\text { Multiseptated } \\
\text { cyst } \\
\text { Left ovary: } \\
27.5 \mathrm{~mm} \\
\text { Right ovary } \\
37 \mathrm{~mm}\end{array}$ & 11 months \\
\hline & 33 wk & $1590 \mathrm{~g}$ & $\begin{array}{c}\text { Bilateral } \\
\text { Inguinal hernia } \\
\text { surgery } \\
\text { At } 3 \text { weeks }\end{array}$ & - & $\begin{array}{l}36 \text { weeks } \\
\text { from GA } \\
(3 \text { weeks) }\end{array}$ & $\begin{array}{l}\text { Genital, } \\
\text { pubic } \\
\text { swelling }\end{array}$ & $\begin{array}{c}\mathrm{LH}: 19.3 \\
\mathrm{mUI} / \mathrm{mL} \\
\mathrm{FSH}: 7.8 \\
\mathrm{mUI} / \mathrm{mL} \\
\mathrm{Est}: 720 \\
\mathrm{pg} / \mathrm{mL} \\
\text { tumors } \\
\text { markers negative }\end{array}$ & $\begin{array}{c}\text { Multiseptated } \\
\text { cyst } \\
\text { Left ovary: } \\
37 \times 30 \mathrm{~mm} \\
\text { Right ovary: } \\
19 \times 9 \mathrm{~mm}\end{array}$ & - \\
\hline Bethany 2018 & $\begin{array}{c}242 / 7 \\
\text { wk } \\
\text { (twin) }\end{array}$ & - & - & - & $\begin{array}{l}43 \text { weeks } \\
\text { from GA } \\
\text { (5 months) }\end{array}$ & $\begin{array}{c}\text { VB: } \\
\text { Once more }\end{array}$ & $\begin{array}{c}\mathrm{LH}: 3.8 \mathrm{mUI} / \mathrm{mL} \\
\text { FSH: } 5.4 \mathrm{mUl} / \mathrm{mL} \\
\text { Est: } 53.8 \mathrm{pg} / \mathrm{mL}\end{array}$ & - & - \\
\hline \multirow[t]{2}{*}{ Vogiatzi 2017} & 25 wk & - & $\begin{array}{c}\text { BPD, } \\
\text { 5-month } \\
\text { hospitalization }\end{array}$ & - & $\begin{array}{l}48 \text { weeks } \\
\text { from GA } \\
\text { (6 months) }\end{array}$ & $\begin{array}{c}\text { VB: } \\
\text { Once more } \\
\text { B:2 }\end{array}$ & - & $\begin{array}{l}\text { Follicles: } \\
35 \mathrm{~mm}, 33 \\
\text { mm (left } \\
\text { ovary) }\end{array}$ & 10 months \\
\hline & $24 w k$ & - & $\begin{array}{c}\text { BPD, PDA } \\
\text { closure surgery }\end{array}$ & - & $\begin{array}{l}47 \text { weeks } \\
\text { from GA }\end{array}$ & VB & - & - & - \\
\hline Perez-Milicua 2017 & $\begin{array}{c}24 \\
6 / 7 \text { wk }\end{array}$ & - & $\begin{array}{c}\text { BPD, PPH, PDA, } \\
\text { ASD, ROP, } \\
\text { Adernal } \\
\text { hemorrhage }\end{array}$ & $\begin{array}{c}\text { leuprolide } \\
3.75 \text { every } 28 \\
\text { days }\end{array}$ & $\begin{array}{l}37 \text { weeks } \\
\text { from GA } \\
(3.5 \\
\text { month) }\end{array}$ & $\begin{array}{l}V B \\
B: 3\end{array}$ & $\begin{array}{c}\text { LH: } 1.3 \mathrm{mUI} / \mathrm{mL} \\
\text { FSH: } 3.1 \mathrm{mUI} / \mathrm{mL} \\
\text { Est: } 125 \mathrm{pg} / \mathrm{mL} \\
\text { INB: } 120 \mathrm{pg} / \mathrm{mL}\end{array}$ & $\begin{array}{l}\text { Uterus: } \\
\text { Pre pubertal } \\
\text { Follicles: } \\
12 \mathrm{~mm} \\
\text { (Right Ovary) }\end{array}$ & $\begin{array}{l}\text { Treatment with } \\
\text { GnRH Agonist } \\
\text { till } 2 \text { years old }\end{array}$ \\
\hline $\begin{array}{l}\text { Mosalla Nejad } \\
2016\end{array}$ & $30 \mathrm{wk}$ & $1500 \mathrm{~g}$ & $\begin{array}{c}\text { RDS } \\
32 \text { days } \\
\text { hospitalization }\end{array}$ & - & $\begin{array}{l}38 \text { weeks } \\
\text { from GA } \\
\text { ( } 2 \text { months })\end{array}$ & $\begin{array}{c}\text { Swelling } \\
\text { labia Major }\end{array}$ & $\begin{array}{c}\mathrm{LH}: 0.8 \mathrm{mUI} / \mathrm{mL} \\
\text { FSH: } 4.6 \mathrm{mUI} / \mathrm{mL} \\
\text { Est: } 34 \mathrm{pg} / \mathrm{mL}\end{array}$ & $\begin{array}{c}\text { Uterus: } \\
39 \times 8 \times 12 \mathrm{~mm} \\
\text { Follicles: } \\
18 \mathrm{~mm}, 15 \\
\mathrm{~mm} \text { (left } \\
\text { ovary) }\end{array}$ & 3.5 months \\
\hline de Lange 2011 & $\begin{array}{c}25 \\
4 / 7 \text { wk }\end{array}$ & & $\begin{array}{l}\text { Brain MRI: } \\
\text { Likely Rathke cleft } \\
\text { cyst }\end{array}$ & $\begin{array}{l}\text { GnRH Agonist } \\
\text { q } 28 \text { Daily } \\
\text { till 18-month- } \\
\text { old }\end{array}$ & $\begin{array}{l}41 \text { weeks } \\
\text { from GA } \\
\text { (4 months) }\end{array}$ & $\begin{array}{l}\text { VB } \\
\text { B }\end{array}$ & - & - & 18 months \\
\hline
\end{tabular}


Table 2. Continued.

\begin{tabular}{|c|c|c|c|c|c|c|c|c|c|}
\hline Studies & $\begin{array}{l}\text { Birth } \\
\text { GA }\end{array}$ & Weight & $\begin{array}{l}\text { Background } \\
\text { Disease }\end{array}$ & $\begin{array}{l}\text { Drugs and } \\
\text { Interventions }\end{array}$ & $\begin{array}{l}\text { Age at } \\
\text { Onset of } \\
\text { Puberty } \\
\text { Changes }\end{array}$ & $\begin{array}{l}\text { Clinical } \\
\text { features }\end{array}$ & $\begin{array}{l}\text { Prime Levels of } \\
\text { Hormones }\end{array}$ & $\begin{array}{l}\text { Sonography } \\
\text { Findings }\end{array}$ & $\begin{array}{c}\text { Age at } \\
\text { Complete } \\
\text { Regression }\end{array}$ \\
\hline \multirow{4}{*}{$\begin{array}{l}\text { Sedin } 1985 \\
\text { (radioimmunoassay } \\
\text { tests) }\end{array}$} & $26 w k$ & $852 \mathrm{~g}$ & $\begin{array}{c}\text { RDS, } \\
\text { Prematurity apnea }\end{array}$ & $\begin{array}{c}\text { CAPP } \\
\text { Theophylline } \\
\text { Left } \\
\text { Oophorectomy } \\
\text { MPA for } 8 \\
\text { months }\end{array}$ & $\begin{array}{c}36 \text { weeks } \\
\text { from GA } \\
(2.5 \text { month) }\end{array}$ & $\begin{array}{l}\text { labia Major } \\
\text { Swelling }\end{array}$ & $\begin{array}{c}\text { Est:5300 } \\
\text { pmo/L }\end{array}$ & $\begin{array}{c}\text { Uterus: } \\
37 \times 17 \mathrm{~mm} \\
\text { Ovaries } \\
\text { multiseptated } \\
\text { cyst } 4 \mathrm{~cm}\end{array}$ & $\begin{array}{c}60 \\
\text { weeks from } \\
\text { GA } \\
\text { (8 month) }\end{array}$ \\
\hline & $28 w k$ & $767 \mathrm{~g}$ & $\begin{array}{c}\text { SGA, RDS } \\
\text { Prematurity apnea }\end{array}$ & $\begin{array}{c}\text { CAPP } \\
\text { Theophylline } \\
\text { MPA }\end{array}$ & $\begin{array}{c}38 \text { weeks } \\
\text { from GA } \\
(11 \text { weeks })\end{array}$ & $\begin{array}{l}\text { Labia } \\
\text { Major, } \\
\text { Pubic } \\
\text { Swelling }\end{array}$ & $\begin{array}{c}\text { Est: } \\
\text { 2000-3000 } \\
\text { pmo/L }\end{array}$ & $\begin{array}{c}\text { Multiseptated } \\
\text { cyst ovaries }\end{array}$ & $\begin{array}{c}60 \\
\text { weeks from } \\
\text { GA }\end{array}$ \\
\hline & $28 w k$ & $794 \mathrm{~g}$ & RDS & $\begin{array}{c}\text { HFPPV } \\
\text { CPAP } \\
\text { Theophylline }\end{array}$ & $\begin{array}{l}39 \text { weeks } \\
\text { from GA }\end{array}$ & $\begin{array}{l}\text { Slight labia } \\
\text { Major } \\
\text { Swelling }\end{array}$ & $\begin{array}{c}\text { Est:2000 } \\
\text { pmo/L }\end{array}$ & $\begin{array}{l}\text { Follicles: } \\
\text { 9-10 mm }\end{array}$ & $\begin{array}{l}48 \text { weeks } \\
\text { from GA }\end{array}$ \\
\hline & 24 wk & $625 \mathrm{~g}$ & BPD & $\begin{array}{c}\text { HFPPV } \\
\text { NCPAP } \\
\text { Theophylline } \\
\text { Diuretic drugs }\end{array}$ & $\begin{array}{l}30 \text { weeks } \\
\text { from GA }\end{array}$ & & $\begin{array}{c}\text { Est:960-2000 } \\
\text { pmo/L }\end{array}$ & $\begin{array}{l}\text { Follicles: } \\
\text { 9-10 mm } \\
\text { Till } 3 \text { months } \\
\text { old }\end{array}$ & $\begin{array}{c}36 \\
\text { weeks } \\
\text { from GA }\end{array}$ \\
\hline
\end{tabular}

GA, gestational age; BPD, bronchopulmonary dysplasia; HFPPV, High frequency positive pressure ventilation; NCPAP, Nasal continuous positive airway pressure; PDA, patent ductus arteriosus; $\mathrm{ICH}$, intracranial hemorrhage; Est, Estradiol serum; ROP, retinopathy of prematurity; PPH, persistent pulmonary hypertension; MPA, medroxyprogesterone acetate; RDS, respiratory distress syndrome; SGA, Small for gestational age; ASD, Atrial septal defect; $\mathrm{CH}$, congenital hypothyroidism.

symptoms and a decrease in oxygen demand.

The levels of hormones mentioned in several studies did not necessarily coincide with the severity of clinical symptoms, indicating the effect of other factors such as the method and accuracy of laboratory tests, different sensitivity of the receptors in the sexual organs in the patients, medications (drugs used) and inflammatory factors due to the severity of chronic and systemic diseases (Table 2).

There cannot be any cutoff point in gonadotropins and sex hormones serum levels to distinguish mini puberty from CPP due to serious etiology such as tumors that need GnRH agonist to be assessed. Thus, serum levels of gonadotropins and sex hormones are higher in premature infants than in normal term infants with mini puberty.

Ultrasound data of mini puberty ovarian maturation are dominant to uterine size. In the patient of this study, ovarian follicle size was over $10 \mathrm{~mm}$, contrary to Kurtoğlu and Baştuğ's study ${ }^{6}$ and similar to studies conducted by Sedin et al, Perez-Milicua et al, Vogiatzi et al, Mosallanejad et al, and Vorgucin et al. ${ }^{13,15,18-20}$

In line with the results reported by Sedin et al, ${ }^{13}$ in this study, despite the decrease in sex hormone levels and reduction of uterine size and ovarian volume, follicles with the size of $9 \mathrm{~mm}$ were observed on sonography, suggesting the development and atrophy of the follicles that are not necessarily related to puberty improvement.

In the study by Sedin et al, multiple ovarian cysts with an average diameter of $21 \mathrm{~mm}$ were found. In $50 \%$ of the cases, reduction in the cysts is observed in the first month and in $25 \%$ of the cases, in the second month. It may persist longer than three months in $10 \%$ of the cases. ${ }^{13}$

If the cysts do not become smaller without clinical reduction, MPA can be prescribed to decrease the synthesis of ovarian estradiol. ${ }^{13}$ However, it should be noted that if regression of clinical symptoms is seen, medical treatment may not be necessary because the enlargement and shrinkage of the follicles are natural up to the age of two. In the study by Sedin et al, medroxyprogesterone was suggested for treatment with estradiol above $2000 \mathrm{pmo} / \mathrm{L}$ (radioimmunoassay), which is not recommended because the fluctuating estradiol levels during the first two years of life are proportional to the changes in the size of the follicles. ${ }^{13}$ Although treatment with medroxyprogesterone causes a faster reduction in estradiol levels, due to the important sexual development roles of hormonal changes during the mini-puberty period, minimal therapeutic interventions during this particular period are recommended. ${ }^{13}$

To prevent torsion, aspiration drainage is recommended in cysts that are larger than $4-5 \mathrm{~cm} .{ }^{6}$ However, the normal pathology of a $4 \mathrm{~cm}$ multiloculated ovarian cyst in the patient reported by Sedin et al (who had undergone unilateral oophorectomy and then observation of enlarged ovarian cysts which were treated with medroxyprogesterone for some time) shows that hasty surgery should be avoided. In fact, the main pathology is not in the ovaries but is caused by an exaggerated increase in the secretion of gonadotropins during mini puberty due to prematurity which is temporary. Therefore, it is better to use 'exaggerated mini puberty' instead of ovarian hyperstimulation syndrome in preterm infants. ${ }^{13}$ Brain MRI, evaluating hypothalamus and pituitary, is recommended to rule out brain insult (tumor or anatomic disorders).

One of the premature infants in the study by Sedin et al had no clinical signs of puberty. Only periodical tests showed increased levels of estradiol serum and about 


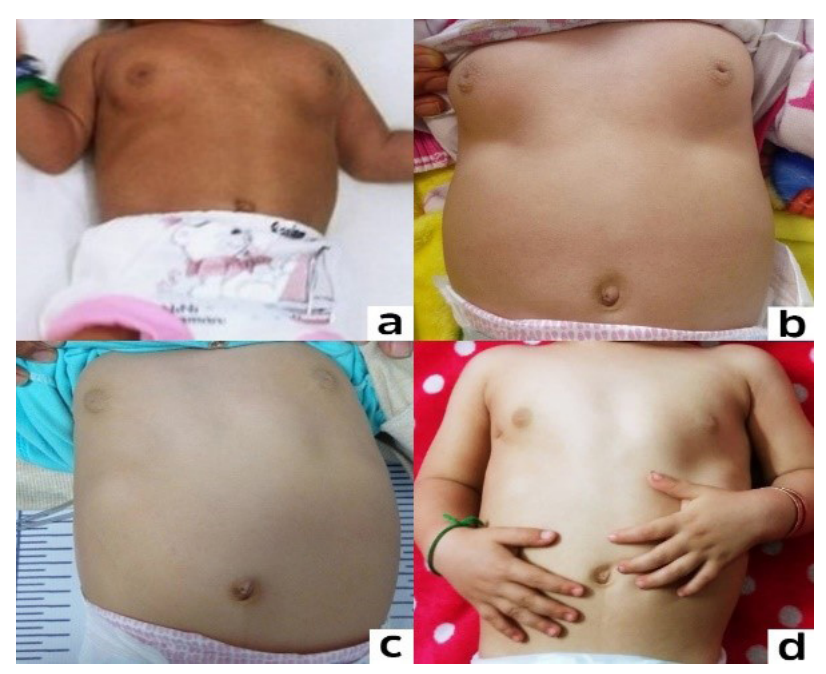

Figure 1. Notice the Regression in the Size of the Breasts During One Year of Follow up. a) 6 months, b) 9 months, c) 13 months, d) 18 months.

10-mm ovarian follicles till the age of 15 months which indicated the dynamic process of mini puberty even without clinical presentations. In a more comprehensive plan with periodic monitoring such as hormonal testing, uterine and ovarian ultrasound observations, and attention to the clinical changes, it is possible to get better understanding of the pattern of mini-pubertal changes and their importance in this critical period of life in the VLBW premature infants. ${ }^{13}$

It is found that after ruling out serious etiologies for precocious puberty in preterm infants, with careful monitoring, patients gradually return to the pre-pubertal stage, without any additional hormonal intervention.

In conclusion, mini puberty is one of the most important events of infancy with intermittent changes related to puberty presentations, and is of significant importance for sexual development in both sexes. In premature infants, exaggerated mini puberty is an intermittent state with severe puberty changes in clinical, laboratory, and sonography data. The levels of gonadotropins in the preterm infants are higher and more extended than in term newborns, particularly in girls. The mean preterm birth GA of infants with exaggerated mini puberty symptoms was 26.3 weeks, (SD: 2.6, range: $24-33$ weeks) and the mean birth weight was $963 \mathrm{~g}$ (SD: 345, range: 625-1590). Almost all of them had a history of long-term hospitalization for prematurity problems, especially BPD.

The mean onset of obvious signs of puberty in these infants was 39.28 weeks, (SD: 4.5 , range: $30-48$ weeks) and on the average, it was 3.5 months after birth (SD: 1.4, range: 3 weeks to 6 months). The age of termination of puberty symptoms was very diverse from about 2 weeks to 13 months, due to the severity of puberty presentations.

The severity and association of puberty symptoms such as vaginal bleeding, thelarche tanner above stage 2, pubic hair, very high levels of gonadotropins and gonadal steroids, and ovarian follicle size in preterm infants are not enough reasons to start treatment. It seems that paying attention to any puberty changes in very premature infants can help in better recognition of exaggerated mini puberty pattern during this important period of life.

\section{Acknowledgments}

The authors would like to thank the parents of the patient who kindly provided us with the photos to be published.

\section{Authors' Contribution}

MAD, FG, GM and AAH: Study conception and design. MAD, FG, GM and AAH: Manuscript preparation, supervision, administrative support and critical revision of the paper. All authors read and approved the final manuscript.

\section{Conflict of Interest Disclosures}

All authors declared no conflicts of interest.

\section{Ethical Statement}

As neonates are not capable of providing ethical consent to participate, their parents provided a written informed consent. The parents provided written informed consent for publication.

\section{Funding}

This research did not receive any specific grant from funding agencies in the public, commercial, or not-for-profit sectors.

\section{References}

1. Rey RA. Mini-puberty and true puberty: differences in testicular function. Ann Endocrinol (Paris). 2014;75(2):58-63. doi: 10.1016/j.ando.2014.03.001.

2. Copeland KC, Chernausek S. Mini-puberty and growth. Pediatrics. 2016;138(1):e20161301. doi: 10.1542/peds.20161301.

3. Forest MG, Cathiard AM, Bertrand JA. Evidence of testicular activity in early infancy. J Clin Endocrinol Metab. 1973;37(1):148-51. doi: 10.1210/jcem-37-1-148.

4. Kuiri-Hänninen T, Sankilampi U, Dunkel L. Activation of the hypothalamic-pituitary-gonadal axis in infancy: minipuberty. Horm Res Paediatr. 2014;82(2):73-80. doi: 10.1159/000362414.

5. Melmed S, Macp M, Koenig R, Rosen C, Auchus R, Goldfine A. Williams Textbook of Endocrinology E-Book. Elsevier; 2020.

6. Kurtoğlu S, Baştuğ O. Mini puberty and its interpretation. Turk Pediatri Ars. 2014;49(3):186-91. doi: 10.5152/tpa.2014.2038.

7. Stoupa A, Samara-Boustani D, Flechtner I, Pinto G, Jourdon I, González-Briceño L, et al. Efficacy and safety of continuous subcutaneous infusion of recombinant human gonadotropins for congenital micropenis during early infancy. Horm Res Paediatr. 2017;87(2):103-10. doi: 10.1159/000454861.

8. Bonomi M, Vezzoli V, Krausz C, Guizzardi F, Vezzani S, Simoni $M$, et al. Characteristics of a nationwide cohort of patients presenting with isolated hypogonadotropic hypogonadism (IHH). Eur J Endocrinol. 2018;178(1):23-32. doi: 10.1530/eje17-0065.

9. Lanciotti L, Cofini M, Leonardi A, Penta L, Esposito S. Up-to-date review about minipuberty and overview on hypothalamic-pituitary-gonadal axis activation in fetal and neonatal life. Front Endocrinol (Lausanne). 2018;9:410. doi: 10.3389/fendo.2018.00410.

10. Quinton R, Mamoojee $\mathrm{Y}$, Jayasena CN, Young J, Howard S, Dunkel L, et al. Society for Endocrinology UK guidance on the evaluation of suspected disorders of sexual development: emphasizing the opportunity to predict adolescent pubertal failure through a neonatal diagnosis of absent minipuberty. Clin Endocrinol (Oxf). 2017;86(2):305-6. doi: 10.1111/ cen.13257.

11. Dwyer AA, Jayasena CN, Quinton R. Congenital hypogonadotropic hypogonadism: implications of absent 
mini-puberty. Minerva Endocrinol. 2016;41(2):188-95.

12. Johannsen TH, Main KM, Ljubicic ML, Jensen TK, Andersen $H R$, Andersen MS, et al. Sex differences in reproductive hormones during mini-puberty in infants with normal and disordered sex development. J Clin Endocrinol Metab. 2018;103(8):3028-37. doi: 10.1210/jc.2018-00482.

13. Sedin G, Bergquist C, Lindgren PG. Ovarian hyperstimulation syndrome in preterm infants. Pediatr Res. 1985;19(6):548-52. doi: 10.1203/00006450-198506000-00009.

14. de Lange AH, Bocca G. Vaginal bleeding in a 4-monthold preterm girl: extreme minipuberty mimicking central precocious puberty. J Pediatr Endocrinol Metab. 2013;26(56):595-7. doi: 10.1515/jpem.2011.363.

15. Perez-Milicua G, Kaiserman J, Oleka C, Bercaw-Pratt JL. Minipuberty of infancy in extreme prematurity. J Pediatr Adolesc Gynecol. 2017;30(2):295-6.

16. Becker M, Oehler K, Partsch CJ, Ulmen U, Schmutzler R, Cammann $\mathrm{H}$, et al. Hormonal 'minipuberty' influences the somatic development of boys but not of girls up to the age of 6 years. Clin Endocrinol (Oxf). 2015;83(5):694-701. doi: 10.1111/cen.12827.

17. Sperling MA. Pediatric Endocrinology E-Book. Philadelphia, PA: Elsevier Health Sciences; 2014.

18. Vogiatzi MG, Pitt M, Oberfield S, Alter CA. Menstrual bleeding as a manifestation of mini-puberty of infancy in severe prematurity. J Pediatr. 2016;178:292-5. doi: 10.1016/j. jpeds.2016.08.021.

19. Mosalla Nejad A, Tabatabai S, Shakiba M, Alaei MR, Saneifard $\mathrm{H}$. A rare case of ovarian hyperstimulation syndrome in a preterm infant. J Clin Diagn Res. 2016;10(11):SD07-SD8. doi: 10.7860/jcdr/2016/21562.8880.

20. Vorgucin I, Katanic D, Kovacevic B, Vislavski M, Bajkin I, Stankovic S. Preterm ovarian hyperstimulation syndrome: a clinical presentation of three cases. J Gynecol Neonatal Biol. 2018;4(1):14-7. doi: 10.15436/2380-5595.18.1802.

21. Bethany M, Candace Percival. Menstrual Bleeding in Former Micro Preemie as Presentation of Exaggerated Mini-Puberty. J Pediatrics. 2018;142(1_MeetingAbstract):601. 